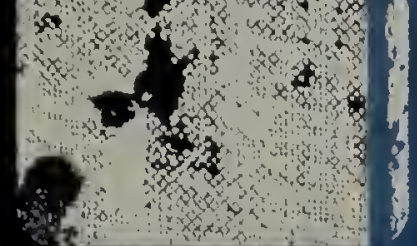

Analytical table of Lindley's - natural orders of the vegetable kingdom.

Tax

L64

$\mathrm{V}$

$1874 \mathrm{a}$ 


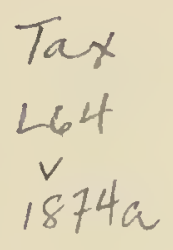

HARVARD UNIVERSITY

\author{
LIBRARY
}

OF THE

GRAY HERBARIUM 


\section{ANALY'ICAL TABLE}

OF

LINDLEYS NATURAL ORIDER

of THF

\section{VBGETABLE KINGDOM.}

$:$

BOSTON.

1874 

L $64 \mathrm{~V}$

$1.574 a$

\section{ANALYTICAL TABLE}

OF

\section{LINDLEY'S NATURAL ORDERS OF PLANTS.}

MODIFILD FROM

BALFOUR'S CLASS BOOK OF BOTANY.

MASSACHUSETTS INSTITUTE OF TECHNOLOGY, 1874.

Flowerless plants, reprodueing by spores. Cryprogamia. D. Flowering plants, reproducing by seeds.

Embryo with a single cotyledon. l'arts of the flower in 3 's. Leaves mostly parallel veined. Woody bundles of the stem scattered among the eellular tissue. Endogenous. C.

Embryo with two or more cotyledons, - or none. Parts of the flower in 5's or 4's, or indefinite. Leaves net veined. Woody bundles of the stem symmetrically arranged around a central pitl. Exogenous.

Flowers having a ealyx only, which is sometimes eorolla like. Apetalous. B.

Flowers having neither ealyx nor corolla. Asepalous. B. Flowers having both ealyx and corolla.

Petals partly or wholly united - or monopetalous. A. Petals distinct, or polypetalous.

Stamens and corolla inserterl on the receptacle. I, a. p. 3. Stamens and petals iuserted on the calyx. I, b. p. 8 . 
A. - Corolla am stamens insertent on the calyx. I, c. p. 12. Corolla inserted on the receptacle.

Stamens inserted on the receptacle and distinct from the corolla. I, d. p. 14.

Stamens arherent to the corolla. I, e. p. 14.

B. - Stigma none. Seeds not enclosed in a pericarp. Embryo with more than two cotylerlons. - rarely two.

Gymposperms. II, b. p. 20.

Stigma present. Ovules in a pericarp.

Embryo with tro cotyledons. Axgiosprems. II, a. p. 17. Fmbryo acotyledonous. Simoriss. II, c. p. 21.

C. - Leares net reiner. III, a. p. 21.

Leaves parallel veined.

Perianth glumaceous, or consisting of imbrieated bracts, mostly in pairs. III, e. p. 25.

Perianth not glumaceons.

Perianth ardherent to the ovary, flowers complete.

III, b. p. 22.

Perianth free from the ovary, flowers complete.

III, c. p. 23 .

Perianth none, flower's incomplete. III, d. p. 24.

D. - With a distinct stem hearing leaves or branches, and having wooly tissue and ressels. Acrorkess. IV, a. p. 25.

With 110 distinetion of stem and leares, but consisting of rariously formed expansions of cellular tissue.

Timaliogens. IV, b. p. 26.

In the following pages p. refers to the page of Gray's . Findu. Forest and Ginren Botany" on which the order is described.

The mark t indicates that Gray refers the plants to a ditferent natmial orten.

When a matural order is given withont reference to Gimy, the flints inclusterl in the order are not fomed in the Luiterl States. 


\section{I, a. - THALAMIFLORAL ExOGENS.}

Stamens ferrer than 20 . 6

Stamens more than 20.

Leaves with stipules. 4

Leaves without stipules.

Carpels combined into a single ovary. Placentas more than one. 1

Carpels distinct, - or solitary.

Stamens united into one set or more. Hypericacers. p. 61 Stamens distinct.

Carpels immersed in a flat-topped, fleshy disc.

Carpels not immersed in the disc.

Nelumbacex. p. 46 ;

Embryo enclosed in a vitellus or sac. Aquatic.

Cabombacem.

Embryo not enclosed in a vitellus, - minute.

Seeds witly all aril. Trees or shrubs. Difleniaces.

Seeds without an aril.

Albumen of the seeds mottled. Anovaces. p. 43.

Albumen of the seeds homogencous.

Flowers perfect, having both stamens and pistils.

RanunCUlaces. p. 33.

Flowers imperfect, - some staminate, some pistillate. Trailing shrubs. Scuizaxdraced.

1.-Placentas in the axis. 2

Placentas parietal.

Seeds without albumen. CAPPALIDACEs. p. 56

Seeds albuminous.

Embryo in a vitellus, or вac. Aquatic. Nraprexacess. p. 46. Embryo not in a vitellus.

Seeds containcd in a pulp. Juice watery. Fuacourrraces. Seeds not contained in a pulp. Juice milky. 
2. - Stigma petaloid, umbrelia like. Sarracinacedi. p. 47. Stigma simple, not peculiar.

Leaves eompound. RHizonolaces.

Leaves simple.

Petals not as many as the sepals. Teristroniacex.

Petals as many as the sepals.

Seeds numerous. 3

Seeds few.

Stigma nearly sessile, radiating or peltate. GutTIFERx.

Stigma on a distinct style, - live lobed. Hummacex.

3. - Petals flat. MARCGRMIICEA.

Petals crumpled. Cistaces. p. 60.

4. - Cirpels distinct, numerous. MLGxomacer. p. 42.

Carpels eombined into a solid pistil. More than one placenta.

Calyx valvate in the bud. $\mathbf{5}$

Calyx imbricated or twisted in the bud.

Flowers in heads, having in involucrum. CHLAENACEA.

Flower's separate, having no involucrum. CIsTACE. p. 60.

5. - Calyx irregular, - enlarged in fruit. Dipterocarpaces.

Calyx regular, - not enlarged in fruit.

Stamens distinct. TiLIaces. p. 75.

Stamens united wholly or partially.

Anthers one celled. Marracer. p. $70 . \therefore$,

Anthers two celled.

Stamens columnar, all perfect. Sterochacke. p. 75.

Stamens not columnar, - some witlont anthers.

BYTTAERIACEX.

6. - Leaves with stipules. 16

Leaves witlout stipules.

Carpels combined into a solid pistil or ovary. 7

Carpels distinct, or solitily.

Anthers with recurved valves. likrberidaces. p. 44.

Anthers with longitudinal valves.

Albumen of secds scanty, - or none.

MLNispenaCEAs. p. 44.

Albumen of seeds abundant. Embryo minute. 
Flowers all imperfect, some staminate, some pistillate. Seeds numerous. LARDIZABALACEA.

Flowers partly imperfect, some staminate, some pistillate, some perfeet. Seerls one or two. Xanthoxilacks. p. $82 . \dagger$ Flowers all perfect.

Embryo in a vitellus, or sac. Aquatic. Cabonbaces. Embryo not in a vitellus.

Seeds with a mottled albumen. Shrubs. AxOnaCEs. p. 42. Seeds with a homogeneuns albumen. Herbs.

Sepals two. Fumaricex. p. 49.

Sepals more than two. Ravuxculaced. p. 33.

7. - Placentas covering the dissepiments. Aquatic.

Nymphader. p. 46.

Placentas in the axis. 9

Placentas parietal.

Stamens tetradynamous, four long aud two sholt.

Crucifere, p.

Stamens not tetradynamons.

Disc small, or none. 8

Dise large.

Parts of flower in 4's. Fruit closed at apex.

Carparidacha. p. 56.

Parts of flower not in 4's. Fruit open at apex.

RESEDACEA. \%. 57.

8. - Albumen of seeds scanty ol none. FrankENiACEs.

Albumen of seerls abundant.

Fruit fleshy with a centril pulp. Flacourtiacex.

Fruit withont pulp. Juice milky. Paraveracke. p. 48.

9. - Styles more or less united. 10

Styles separate to the base.

Calyx ralvate in the bud. Virianaces.

Caly $x$ imbricate in the bud.

Petals twisterl in the burl. Fmbryo straight. ILINACEA. p.77

Petals not twisted. Embryo enrved.

Caryopullateris. p. 63. 
10. - Fruit gynobasic, having the apices of the carpels united to the summit of the axis. 14

Fruit not gynobasic.

Calyx valvate in the bud. $\mathbf{1 2}$

Calyx imbricate in the bud.

Calyx irregular. 13

Calyx regular.

Carpels less than four. 11

Carpels four or more.

Seeds winged. Ceurelacket.

Seeds wingless.

Stamens united into a long tube. MetiacE出. p. 84 .

Stamens separate or nearly so.

Leares dotted. Atrantuckas. p. 83. †'

Leaves without dots. BrixiACE.E.

11. - Seeds hairy or downy. Thuraricaceido p. 63.

Seeds not liairy.

Ovules ascending or horizontal. P'ITTOSPORACEZ. p. 57.

Ovules suspended. Crrildaces.

12. - Anthers opening by pores. Trmandracent.

Anthers opening by slits.

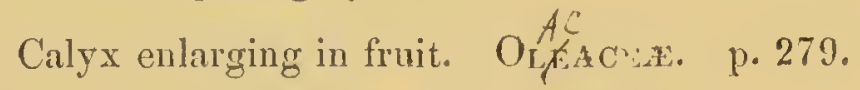

Calyx continuing small. Icacivaced.

13. - Flowers symmetrical. Getrtaks.

Flowers unsymmetrical.

Petals with appendages at base. SAPIKDACE, p. 88.

Petals without appendages at base.

Fruit a samara, with a membranaceous wing.

AChrace.e. p. 91.

Fruit not a samara. Flowers having a papilionaceous aspect.

Ovary two celled. Polmatace.e. p. 92,

Ovary one eclled. Krankitacka.

14. - Stamens arising from scales. Sinarúbcede p. 83.

Stamens not arising from scales.

Styles separate at the apex. 15

Styles wholly united into one. 
Flowers all perfect. Rutaces. p. 81.

Flowers partly imperfect, sone staminate, some pistillate, some perfect. Xanthoxylaces. p. $82 . \dagger$

15. - Flowers regular. LimnantuaCeas. p. 77.†

Flowers irregular.

Fruit with elastic, recurved valves. Balsaminaces. p. $81 . \dagger^{\dagger}$

Fruit without elastic valves. Tropaolacen. p. $81 . \dagger$

16. - Carpels distinct or solitary. Anthers with recurved valves. BERBERIDACE. p. 44.

Carpels united. More than one placenta.

Placentas in the axis. $\mathbf{1 7}$

Placentas parietal.

Leaves rolled up in the bud, with glandular hairs.

Droseraueze p. 59.

Leaves straight in the bud, without glandular hairs.

VIOLACEX. p. 58.

17. - Styles more or less united. 18

Styles distinct to the base.

Calyx valvate in the bud. TItraceis. p. 75.

Calyx imbricate in the bud.

Marsh plants. Petals small, sessile. Earatinacex. p. 63.

Trees or shrubs. Petals conspicuous, stalked.

Malpighuace.

18. $\rightarrow$ Fruit gynobasic, with the carpels attached to the apex, 20 Fruit not gynobasic.

Calyx valvate in the bud. 19

Calyx imbricate in the bud.

Flowers in heads, with an involucrum. Cif Lenaces.

Flowers without an involucrum.

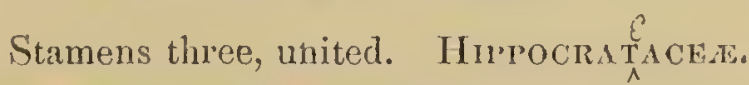

Stamens more than three.

Calyx glandular. Marptemacex.

Calyx not glandular.

Embryo curved. Sapindachas. p. 88.

Embryo straight. Erxturoxylaces. 
19. - Stamens arranged in a column. Stercurtacex. p. 75. Stamens not columuar.

Stamens opposite the petals. VtrACE.E. p. 85.

Stamens alternate with the petals, or numerous.

TILIACEA. ‥ 75 .

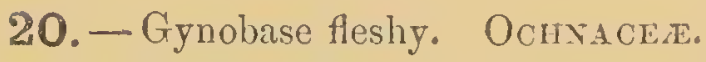

Gynobasc dry.

Leaves regularly opposite. ZrgopIIYLACAE.

Leaves mostly alternate.

Fruit beaked. Gerantaces. p. 77.

Fruit not beaked. OxaLidicede. p. 77. $\dagger$

I, B. CALXCTFLORAL EXOGENS. Polypetalons.

Stamens less than twenty. I

Stamens more than twenty.

Ovary inferior or partially so.

Ovary wholly superior.

Leaves with stipulcs. 2

Lcaves without stipules.

Carpels combincd into a solid pistil, with more than one placenta. 1

Carpels more or less distinct, or solitary.

Ovules suspended or ascending. Rosicex. p. 115.

Ovules attached by a corr to the base of the cell.

ANACARDLACEA p. 84.

1. - Calyz of two sepals cohering at base.

PotTrLACACles, p. 69.

Calyx of nore than two scpals, tubular, permanent.

LTHRACEN. p. 149.

2. Carpels combined into a solid pistil, witl more than onc placenti. Placentas in the axis. Portulacaces. p. 59. Carpcls more or less distinct or solitary.

Calyx with the odd lobe inferior or anterior.

LARUMINOSA. p. 94.

Calyz with the odd lobe superior or posterior.

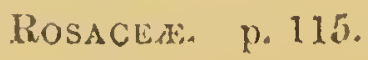


3. - Leaves with stipules. 6

Leaves without stipules.

Placentas in the axis. 4

Placentas parietal.

Petals definite, distinct from calyx, hooded.

LOASACEe. p. 151.

Petals indefinite, passing into sepals. CACTACE.. p. 152.

4. - Leaves without dots. $\mathbf{5}$

Leaves with transparent dots.

Ovary one celled. Cotyledons not distinct.

Chandenu UXac.e.

Ovary more than one celled. Cotyledons distinct.

Mírtítes. p. 149.

5. - Petals indefinite, numerous. Mescinbryantinemacex. p. 156. Petals definite, few.

Petals linear, reflexed. Alangiacez.

Petals round, concave.

Style one, stigma having a round head. Barringtontacere.

Styles and stigmas more than one. Prmladelphacedz. p. 134.

6. - Carpels more or less distinct, or solitary, covered by the calyx. ROSACEx. p. 151.

Carpels united into a solid pistil.

Lcaves opposite. Rinzoproracex.

Leaves alteriate. Fruit a covered cup. Lecithidaces.

7. Ovary inferior, or partly so. $\mathbf{1 7}$

Ovary wholly superior.

Leaves with stipules. 12

Leaves without stipules.

Carpels combined into a solid pistil. 8

Carpels more or less distinct or solitary.

Carpels, each with a hypogynous scale.

Crassulacen. p. 137.

Carpels without hypogynous scales.

Carpels several, all perfect. Calycantinaces. p. 130.

Carpels solitary, or all but one imperfect. 
Leaves dotted. Anyridaces.

Leaves not dotted.

Plants with resinous juice. Anachrdiaces. p. 84.

Plants with watery juice. Comanicere.

8. Placentas in the axis. 9

Placentas parietal.

Flowers imperfect, some staminate, some pistillate.

PAPAYACEE.

Flowers perfect, having both stamens and pistils.

Turneraces.

9. Styles more or less combined. $\mathbf{I O}$

Styles distinct to the base.

Carpels, each with a hypogynous scale. Crassulacez. Carpels two, without scales. Saxirragacles. p.131.

10. Calyx valvate in the bud. 11

Calyx imbricate in the bud.

Sepals two. Portulacacex. p. 69.

Sepals more than tro.

Ovules ascending. Cerastraces. p. 87.

Orules suspended. BruvinCex.

11. - Stamens as many as the petals, and opposite to them.

Riranimaee. p. 86.

Stamens alternate with the petals. Lythraces. p. 149.

12. - Carpels combined into a solid pistil. 13

Carpels distinct, or solitary.

Frruit a pod. Odd sepal inferior. Legumunose. p. 94.

Fruit not a pod. Odd sepal superior. RosaCE is. p. 115.

13. - Placentas in the axis. 14

Placentas parietal.

Flower with a ring of abortive petals.

Passifloracex. p. 157.

Flower without abortive petals. Morrngacer.

14. - Styles more or less combined. 15

Styles distinct to the base. 
Petals minute. IllaCEBRACE.

Petals conspicuous.

Leaves opposite. Cuxoniaces. p. $131 . \dagger$

Leaves alternate. SAxtrragaces. p. 131.

15. - Calyx valvate in the bud. 16

Calyx imbricate in the bud.

Flowers spurred. Vochysiacex.

Flowers spurless.

Leaves simple. Stachiousiaced.

Leaves compound. Stapirleacez. p. $89 . \dagger$

16. - Stamens opposite the petals, of the same number.

Rhamnaces. p. 86.

Stamens alternate with the petals. Ayrmidaces.

17. - Leaves with stipules. 22

Leaves without stipules.

Placentas parietal. Fruit a berry.

Grossulariacedi. p. $133 . \dagger$

Placentas in the axis.

Flowers not in umbels. 18

Flower's in umbels.

Styles two. Unbelifere. p. 162.

Styles more than tivo. Araliaces. p. 166.

18. - Carpels more than one to each flower. 19

Carpels one to each flower.

Plants parasitic. Lorantmacex. p. 292.

Plants not parasitic.

Petals linear, reflexed. Alangraces.

Petals oblong.

- Plants with a resinous juice. Anacardiacess. p. 84.

Plants without a resinous juice.

Cotyledons rolled up. Comiretacis.

Cotyledons flat. Haloragaceas. p. 140.

19. - Calyx limb minute. Haloragacex. p. 140.

Calyx limb conspicuous. 
Carpels not separating at the apex. 20

Carpels separating widely at the apex.

Leaves altemate. Ilerbs. Saxmanacra. p. 131.

Leaves opposite. Shrubs. Humaxriatera. p. I32.†

20.- Callyx not valvate in the bud. 21

Calyx ralvate in the bul.

Embryó curved. 'Tetragoniace. p. $156 . \dagger$

Enbryo straight.

Stamens opposite the petals, and of the same number.

RHAMNACEE. p. 86.

Stamens alternate with the petals, or not of the same number.

Albumen none. Oxagracex. p. 141.

Albumen copious. Corracex. p. 167.

21. - Stimens doubled downwards. Anthers elongated. Leaves ribbed. Metastomace. p. 148.

Stamens not doubled down. Anthers short.

Seeds very numerous, minute. Escildoracex.

- Seeds few, one to four. Briviace.

22. - Placentas parietal. Stipules becoming tendrils.

Cicleimetacez. p. 158.

Placentas in the axis.

Stamens opposite the petals, and of the same number.

$$
\text { Rhauxaces. p. } 86 .
$$

Stamens alternate with the petals, or not of the same number.

Leaves opposite. Ruzorhoracex.

Leaves alternate. Hamanelidaced. p. 140.

I, c. - CALYCIFLORAL ExOGENS. Monopetalous.

23. - Ovary inferior. 24

Ovary superior.

Leaves with minute stipules. Stacrmousiacex.

Leaves without stipules. 
Carpels one to each flower. Stigma with a cup-like covering. Brunontáe.e.

Carpels more than one to each flower.

Carpels separate. Crassetacle. p. 137.

Carpels combined into one fruit.

Flowers perfect, laving both stamens and pistils.

Strracacen. p. 220.

Flowers imperfect, some staminate, some pistillate.

PAPATACEAL.

24.- Carpels more than one in each flower. 26

Carpel one in each flower.

Anthers separate. 25

Anthers united.

Ovule erect. Conposita. p. 179.

Ovule suspended. Caltceraces.

25. - Fruit an achene, with the rudiments of two others.

Vateriasacede. p. 177.

Fruit a single achene, without rudimentary ones.

Fruit crowned with the calyx, and covered with an involucel.

DIPSACACE. p. 178.

Fruit not crowned. No involucel. Lorantmaces. p.292.

26. - Leaves without stipules. 27

Leaves with stipules.

Stipules between opposite petioles. Cincmoxaces. p. 173.

Stipules forming tendrils. Cocurbitaces. p. 158.

27. - Anthers united. Lobelatere. p. 208.

Anthers separate.

Stamens two. Commeditaces.

Stamens more than two.

Authers opening by pores. Vacciniaces. p. $211 . \dagger$

Anthers opening by slits.

Stigma with a covering. Gondentaces.

Stigma without al covering.

Stamens mumerous. Ber.risiactis.

Stamens two, attached to the pistil. STrudiacts.

Stamens four or five. 
Leaves alternate. ChMPANULACEA. P. 209.

Leaves opposite, in pairs. Caplimolacteis. p. 169.

Leaves iu whorls. Galnacex. p. 173.†

I, d.-COROLLIFLORAL EXOGENS. Stamens Hippogynous.

Ovary a single carpel. Stigma with a covering.

BRUNONIACEX.

Ovary composed of two or more carpels.

Anthers opening by pores. 1

Anthers opening by slits.

Leafy resinous plants. Retacex. p. 81 .

Scaly parasitic plants. Moxorropacen. p. 212.†

1. - Herbs. Seeds with a loose covering. Prrolacex. p. 212.

Shrubs. Seeris with an adherent covering.

Antliers two celled, with appendages. Ericacex. p. 210.

Anthers one celled, without appendages. Epacridaces.

I, e.-COROLIIFLORAL ExOGENS. Stamens Perigynous.

Flowers irregular. 10

Flowers regular.

Ovary not dirided into lobes. $\mathbf{I}$

Ovary having three lobes or more.

Flowers arranged in twisted cymes. BoraginaceN. p. 254.

Arrangement of flowers straight. Noranackx. p. 266.

1. - Ovary formed by one carpel. 9

Ovary formed by two carpels. $\mathbf{5}$

Ovary formed by three cirpels. 4

Ovary formed by more than three carpels.

Stamens altermate with the divisions of the corolla. 2

Stamens opposite the divisions of the corolla.

Styles five, rarely three or forr. Prombacinacex. p. 222. Style one. 
'Trees or shrubs. Fruit fleshy. Mrrsixacex.

Herbs. Fruit a capsule. Prmulaced. p. 222.

2.- Carpels separate. AxondCre. p. 43.

Carpels united.

Ovules pendulous. 3

Ovules erect or ascending.

Corolla imbricate in the bud. SAPOTACEA. p. 220.

Corolla plaited in the bud. Convolvulaces. p. 262.

3. - Embryo large. Sapotacee. p. 220.

Embryo small.

Stamens as many as the divisions of the corolla.

ÅUfoliace. p. 218.

Stamens twice as many as the divisions of the corolla.

Erevacex. p. 219.

4. - Herbs. Seedis angular, oval, or winged.

Polemontacede. p. 260.

Undershrubs. Seeds peltate. Drapensiacex.

5. - Stamens four or more. 6

Stamens tivo.

Corolla four cleft. OteptACEx. p. 279.

Corolla five to eight cleft, salver form.

JASMIXACEN. p. 279. †

6. - Flowers not arranged in twisted cymes. 7

Flowers arranged in coiled cymes (scorpioidal).

Fruit a capsule. Hydropmllaceis. p. 258. $\dagger$

Fruit a drupc. Ehretiace.s.

7. - Leaves opposite, whorled, or clustered. 8

Leaves none. Scaly parasites. Cuscutacexs. p. $263 . \dagger$ Leaves alternatc.

Style two cleft. Fruit a drupe. Cordiaces.

Style not two cleft. Fruit a capsule, follicle, or berry.

Leaves with hair like stipules betwcen the petioles.

Leaves without stipules.

ASClePTADACEAS. p. 276.

Ovules few. Flowers plaited in the bud.

Ovules numerous.

Convolvelaches. p. 262. 
Corolla valvate in the bul. Solaxacke. p. 265.

Corolla inmpicate in the bud. Aтropaces. p. $266 . \dagger$

8. - Anthers united to the stigma. Asctermances. p. 276.

Anthers free from the stigma.

Leaves with stipules, often B-5 ribbed. Gextanacezs. p. 270.

Leaves without stipules.

Stigma with an hour-glass contraction. Corolla twisted in the bud. Arocracks. p. 274.

Stigma without a coutraction. Coralla valvate in the bud.

LOGAXIACEN. p. 273.

9. - Fruit one celled, one seeded. Salvadorackis.

Fruit spuriously two celled. Plantaginacex. p. 221.

10. - Ovary four lobed. Flowers in nearly sessile cymes placed in the axils of opposite leaves. Libiatax. p. 243.

Ovary not lober.

Ovary formed by one carpel. Selagivacke.

Ovary formed by two.carpels.

Fruit of four atherent achenes. Verbenaces. p. 241.

Fruit of two coherent achenes. Selaginacex.

Fruit capsular or succulent.

Placentas free, central. Lextrulabtacks. 11. 225.

Placentis in the axis. 11

Placentas parietal.

Seeds winged. Bicrovickar. p. 220 .

Seerts not winger.

Leafless plants. Scaly parasites. Oromincnicrax. 11. 228.

Leafy plants.

Cotyledons minute. Radicle long. Grexinacka. p. 228.

Cotyledons large and fleshy. Radicle short.

Fruit a drupe or capsule. Pemalackes.

Fruit woody with a pulpy interior. CReschentucke.

11. - Secds with albumen. Scropindariacear. p. 229.

Seeds without albumen.

Seeds winged. Bigroxtacex. p. 226.

Seeds without wings attached to hard placen'al processes. ACANTHACEA. p. 239. 


\section{II, a.-APETALOUS ANGIOSPERMS.}

Having a single perianth or calyx. 5

Without a periantl, having neither calyx nor corolla.

Leaves with stipules. $\mathbf{2}$

Leaves without stipules.

Flowers imperfect, some staminate, some pistillate. I

Flowers perfect, laving both stamens and pistils.

Embryo in a vitellus, or sac. Piperacex.

Embryo not in a vitellus. Podostemonace..

1. - Flowers in aments. Carpels single. Mrricaces. p. 395.

Flowers not in aments. Carpels two or more.

Fruit four seeded. Seeds peltate. Aquatic.

Callitrichaces.

Fruit usually three seeded. Seeds not peltate.

Euphorbiace.e. p. 293.

2. - Flowers imperfect, some staminate, some pistillate. 3

Flowers perfect, having both stamens and pistils.

Carpels three or"four. Ovule erect. Embryo in a vitellus, or sac. Marsh herbs. Saururacex. p. 293.

Carpel single.

Ovule erect. Embryo in a vitellus, or sac. Piperacex.

Ovule suspended. Embryo not in a vitellus.

Cimloranthaces.

3. - Ovary with two cells or more. 4

Ovary one celled.

Ovules many, hairy or downy. Salicacex. p. 307.

Ovules not more than two.

Ovule erect. Myricacer. p. 305.

Ovule pendulous. Platanacke. p. 300.

4. - Seeds winged. Altingia CEe.

Seeds wingless. Eurmormiace.e. p. 293.

5. - Ovary inferior, or partly so. $\mathbf{1 7}$

Ovary superior.

Leaves witlı stipules. $\mathbf{1 3}$

Lapaves without stipules. 
Flowers imperfect, some staminate, some pistillate. 9

Flower's perfect, having both stamens and pistils.

Carpels more than one. 8

Carpel single.

Anther valves recurved. Lauraces. p. 290.

Anthers slit lengthwise.

Leaves eovered with scales. EldagNaCidi. p. 292.

Leaves not covered with scales.

Perianth short, segments separate nearly to the base. $\mathbf{7}$

Perianth long or tubular.

Perianth not at all hardened. 6

Perianth partially hardened.

Perianth hardened at base. Nyctagracere. p. 283.

Perianth tube hardened. Scleiranthacex. p. $64 . \dagger$

6. - Stamens in the points of the perianth. Proteacex.

Stamens not in the points of the periantl.

Ovule erect, orthotropal. Pouganacex. p. 287.

Ovule suspended, anatropal. THYMELAaCEA. p. 291.

7. - Stamens attached to the perianth. Basellaces.

Stamens inserted on the receptrele.

Stamens alternate with the segments of the perianth, or numerous. Pirytolacriaced. p. 284.

Stamens opposite the segments of the perianth.

Flowers with braets. Amarantmacke. p. 286.

Flowers without bracts. Chenopodicis. p. 284.

8. - Seeds with albumen. Perianth colored. Embryo eurved around the albumen. Pirtolaccackas. p. 284.

Seeds without albumen.

Perianth not tubular, imperfeet, or spathe like.

Podostenionaces.

Perianth tubular.

Ovary two eelled. Anuilariaced.

Ovary four celled. Plixices.

9. - Carpels more than one, mnited into a solid pistil. 12

Carpels single, or uneombined. 
Perianth open, not tubular. 10

Periantli tubular.

Antleers opening by recurred valves. Atnenosiermace.

Anthers opening lengthwise. MrristiCaces:

10. - Seeds with albumen. 11

Seeds without albumen. Embryo straight.

Perianth two leaved. Casuarinaced.

Perianth many parter. Ceratopirylaces.

11. - Embryo eurved around the albumen.

Cifexopodiacex. p. 284.

Embryo straight. Monmiaces.

12. - Orules numerous. Leaves pitcher like. Nepextiracezs. Ovules ferr.

Orules aseending. Eupetraces.

Ovules suspended. Elphorbiaces. p. 293.

13. - Flowers imperfect, some staminate, some pistillate. $\mathbf{1 5}$

Flowers perfect, having both stamens and pistils.

Carpels more than one, eombined into a solid pistil. $\mathbf{1 4}$

Carpel single.

Stipules single. Petrveriacex.

Stipules sheathing the stem. Polygoxaces. p. 287.

14. - Leaves with round, trausparent, solitary dots. SAmydacez. Leaves without dots.

Perianth regular, in a double row. Chaildetiaces.

Periantlı irregular, in a single row. ULaACEN. p. 296.†

15. - Carpels more than one, eombined into a solid pistil. 16 Carpel solitary.

Anther cells perpendicular to the filament. Struaginace. Anther eells parallel to the filament.

Sap watery. Urticaces. p. 296.

Sap milky. Artocariaces.

16. - Flowers not in aments. Euriorbiaces. p. 293.

Flowers in anents.

Seeds without an aril. BetulaCes. p. 306.

Seeds with an aril. 
Stamen one. Connective of the anther large. LaCistentacex.

Stamens two or more. Connective inconspicuous.

SCEIACE_E.

17. - Leaves with stipules. 19

Leaves without stipules.

Flowers imperfect, some staminate, some pistillate. 18

Flowers perfect, having both stamens and pistils.

Ovary three to six celled, many seeded.

Aristolochincede. p. 282.

Ovary one cellerl.

Style one. Santalacex. p. 292.

Styles three or more. Homaliaces.

18. - Flowers not in aments. DatiscaCEx.

Flower's in aments.

Leaves alternate. Mrricaces.

Leaves opposite.

Leaves simple. Garryaces. p. $167 . \dagger$

Leaves compound. JUGLANDACEN. p. 300.

19. - Flowers imperfect, some staminate, some pistillate.

Flowers perfect, having both stamens and pistils.

Style one. Aristolochides. p. 282.

Styles three or more. HomalaCEa.

20. - Fruit in a cup. Corylaces. p. 302. $\dagger$ Fruit naked.

Fruit simple. Begoniaces. p. 161.

Fruit consisting of many achenes partly immersed in a fleshy receptacle. Antocarpacex.

\section{II, b. GYMNOSPERMS.}

Stem jointed. Gritackx.

Stem not jointer.

Leaves pimate. Cycadacex. p. 309.

Leaves simple. 
Seeds in eones. Conmerz. p. 309.

Seeds solitary, in a berry like scale or enp.

TAXICEA. p. 310.

\section{II, c. SPOROGENS or RIIZANTHS.}

Orules single. Batanorioraces.

Ovules numerons.

Anthers opening by slits. Crtwaces.

Anthers opening by pores. Raffensacex.

Among Thalamifloral Exogens the following orders contain some species with a single perianth or none: Ranuneulneea, Menispermaces, Papaveracee, Flacourtiacea, Caryophyllacex, Sterculiaces, Byttneriacere. Tiliacex, Malpighiacex, Geraniacex, Rutacex, Xinthoxylacex.

Among Calyeifloral Exogens the following orders contain one or more species with a single periantl or none: Celastraeea, Rhimmacex, Amyridacen, Leguminosi, Rosacex, Lythracex, Combretacex, Myrtacere, Halorageacex, Cucurbitacer, Passifloracen, PorEulacacea, Illicebracex, Tetragoniacex, Saxifragacex, Cunoniacex, Loranthaces.

Among Corolliforal Exogens the following orders contain some species with a single perianth or none: Oleaeen, Primulacea.

Some consider Begoniacex, Chailletiacex, Sanylaces, and Homaliace:e as thalamifforal or calyeifforal.

\section{III, a. FADOGENS WITI NET VEINED LEAVES.}

Perianth arllering to the ovary, ovary inferior.

Dloscorace.e. p. 335.

Periantli free from the ovary.

Ovary three to five celled. 1

Ovary one celled.

Parts of flower in fours. Placentas at the base of the ovary. ROXBURGHACEA.

Parts of flower in threes. Philnsinces. 
1.- Flowers imperfect, some staminate, some pistillate. Perianth with six divisions, all petal-like. Leaves articulated with the stem. SmL ACE. p. 336 .

Flower's perfect, having both stamens and pistils. Periantlı with six or eight divisions, all green, or only three petaloid. Leaves not articulater. Triliaces. p. 337.

III, b. AGLUMACEOUS ENDOGENS WITH PERIANTH ADIERENT TO OVARY.

Stamens attached to the pistil. 3

Stamens separate from the pistil.

Veins of the leaves palrallel with the midrib. $\mathbf{1}$

Veins of the leaves rumning parallel from the midrib to the margin。

Stamens five or six, all perfect or bearing anthers.

$$
\text { MUEACEA. p. } 329 . \dagger
$$

Ouly one anther bearing stumen.

Anther one celled. Filament petal-like.

MARANACEE. p. $328 . \dagger$

Anther two celled. Filament not petaloid.

ZiYGHERACEE. p. 328.

Stamens more than six. Aquatic.

1. - Stamens six. 2

HYDROCHARIDCEA. p. 321.

Stamens three.

Anthers opening on the outer side. Einbryo distinet, in a dense albumen. IrHAcke. p. 332.

Authers opening on the imner side:" Embryo in a loose celhlar nucleus. Bumaviacke.

2. - Anthers turned outwards. Bundriacka.

Anthers turneri inwards.

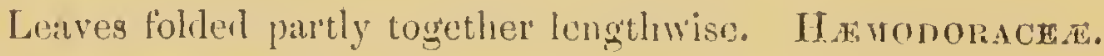

Leaves flat, not folderl.

Fruit one celled. Tacourat.

Fruit three eelled.

Outer perianth green. Albumen mealy. Leaves stiff, channeled, often scurfy. Brombilacks. p. 329.

Outer perianth rolored. Albumen fleshy or hard. 


\section{III, c. ENDOGENS WITH FREE PERIANTH.}

Outer perianth petal like. 2

Outer perianth green, or sometimes glume-like.

Carpels combined into a solid pistil. 1

Carpels more or less separate.

Placentas parietal, forming a net work on the inner surface of the ovary. Fruit many seeded. Butonacl.s. p. 320. Placentas in the axis, or at the base of the ovary.

Anther's opening on the onter side. Embryo straight, with a slit on the side, near the base. Juxcagrnes.

Anthers opening on the inner side. Embryo curved like a horseshoe, with no slit. Alismaces. p. 319.

1. - Whorls of the perianth alike, usually dry and glume-like.

Whorls of the perianth visibly different.

JUYCACEA. p. 349.

Placentas in the axis. Anthers two celled.

COMmelyadez. p. $350 . \dagger$

Placentas parietal. Anthers one celled. Mayacace※.

2. - Carpels combined into a solid pistil. 3

Carpels more or less separate.

Seed solitary. Flowers on a scaly spadix.

Seeds numerous. Flowers not on a spadix.

PalMde. p. $316 . \dagger$

Anthers opening on the outer side. Menanthace.s. p. 337.

\section{Continuation of $\eta .22$.}

Leaves dry. Seeds with a heaked strophiole.

Leaves succulent. Seerls without in strophiole.

Amarilumace. 1). $: 29$.

3. - Ovary one celled. Placentas parietal.

ORUHIMACEA. P. 323.

Ovary three cellerl. Placentas in the axis. Apostasincex. 
1. - Flowers imperfect, some staminate, some pistillate. Periantl with six divisions, all petal-like. Leaves articulated with the stem. Suldack. p. 336 .

Flowers perfect, having both stamens and pistils. Perianth with six or eight divisions, all green, or only three petaloid. Leaves not articulated. TrildidCEa, p. 337.

III, b. AGLUMACEOUS ENDOGENS WITH PLRIANTI ADHERENT TO OVARY.

Stamens attached to the pistil. $\mathbf{3}$

Stamens separate from the pistil.

Veins of the leares pirallel with the midrih. 1

Veins of the leaves rmminy parallel from the midrib to the marring.

Stamens five or six, all perfect or bearing anthers.

Only one anther bearing stamen.

$$
\text { MUEACEA. p. 329. † }
$$

Anther one celled. Filament petal-like.

Anther two celled. Filament not petaloit.

$$
\text { MARANTACE. p. 328. † }
$$

ZINGHERACEA. P. 328.

Stamens more than six. Aquatic.

1. - Stamens six. 2

TYDROCHARTDACEAS. P. 321.

Stamens three.

Anther's opening on the onter sile. Einbryo distinct, in a

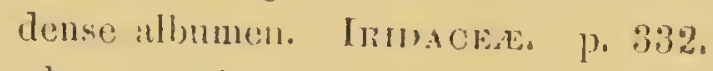

Anthers oneuing mu tha in........... $\cdots$. 


\section{II, c. ENDOGENS WITH FREE PLRIANTI.}

Outer perianth petal like. 2

Outer perianth green, or sometimes glume-like.

Carpels combined into a solid pistil. 1

Carpels more or less separate.

Placentas parietal, forming at net work on the intuer surface of the ovary. Fruit many seeded. Butumacks. p. 320.

Placentas in the axis, or at the base of the ovary.

Anther's opening on the outer side. Embryo straight, with a slit on the side, near the base. JUNCAGINEA.

Anthers opening on the inner side. Embryo curved like a hor'sesloe, with no slit. Alssuaced. p. 319.

1. - Whorls of the perianth alike, usually dry and glume-like.

JUNCACEA. p. 349.

Whorls of the perianth visibly different.

Placentas in the axis. Anther's two celled.

Commennacea. p. $350 . \dagger$

Placentas parietal. Anthers one celled. MAYACACEA.

2. - Carpels combined into a solid pistil. 3

Carpels more or less separate.

Seed solitary. Flowers on a scaly spadix.

PALMA. p. 316. $†$

Seeds numerous. Flowers not on a spadix.

Anthers opening on the outer side. MeranthaCE.. p. 337.

Anthers opening on the inner side.

Perianth of six parts. ButonaCEA. p. 320.

Perianth of two parts. PIILTDRACEA.

3. - Anthers opening on the outer side. Onter perianth glumelike. Xrmunackls. p. 351.

Anthers opening on the inner sile.

Flowers more or less irregular. Perianth rolling inwards after expausion. Aquatic. Pustromaces. p. 322.

Flowers regular. Perianth not rolling invards. 
Inner perianth minute, of a single lobe, or urn shaped, or five toothed. Grumtesincex.

Inner and outer perianth alike. LuLiaclaz. p. 337.

\section{III, d. APETALOUS ENDOGENS.}

Flowers not on a spadix. I

Flowers on a sparlix.

Flowers perfect, having both stamens and pistils.

Orontiaces.

Flowers impcrfect, some staminate, some pistillate.

Embryo without a cleft on the side. Fruit one seeded fibrous nuts, or many celled berries. Pandanace

Embryo with a cleft at one side in which the plunule lies.

Fruit juicy, filaments rery short. Perianth none.

Alzacede. p. 317.

Fruit dry. Filaments long with wedge shaped anthers. Perianth consisting of scales or hairs. Trpuacez. p. 318.

1. - Ovules erect. 3

Ovules suspended.

Carpels several. 2

Carpel single.

Anther's one eelled. Restuckes.

Anthers tiwo celled. Natadace.e. p. 316.

2. - Carpels eombined into a solid pistil. Restracede.

Carpels separate.

Anthers one celled. Desvauxiaces.

Anthers two celler.

Ovary surrounded by a membranous tube.

Ertocaulonacea. p. 352.

Ovary without a surrounding tube. NaAdaces. p. 316 .

Embryo consisting of a cellular nueleus, with no distinction of parts. Thy

Embryo with radiele and plumule eonspienous. 
Flowers naked or furnished with scales. Seeds without a thickened eovering. Foramen not hardened.

NAIADACEA. p. 316.

Flowers eontained in a spathe. Seeds with a thick ribbed covering. Foramen liardened. Pistiacks. p. 316. †

\section{III, e. GLUMACEOUS ENDOGENS.}

Stem hollow. Leaf sheath split. Embryo ontside the albumen at its base. Gramindis. p. 353.

Stem solid. Leaf sheath not split. Embryo within the base of the albumen. CrPeraces. p. 352 .

\section{IV, a. ACROGENS.}

Stem and leaves not distinet. $\mathbf{2}$

Stem and leaves distinet.

Spores without elaters. 1

Spores provided with elaters.

Sporangia opening by four valves. JuxGERMANyIACEA.

Sporangia opening by a fissure lengthwise, collected in cone like heads at the summit of the stem.

EQUiSETACEA. p. 359 .

1. - Sporangia inclosed in two or four valved sporoearps which are situated at the base of the leaves or leaf stalks.

Marsileaces.

Sporangia not inelosed in sporoearps.

Sporangia in the baek or margin of the frond.

FILICES. p. 360.

Sporangia distinct from the leaves.

Sporangia sessile in the axil of leaves.

LI COPODIACEIE. p. 372.

Sporangia borne on stalks. Muscr.

2. - Spores with elaters. MAarchan'riacis.

Spores without elater's. RICCIACE正. 
IV, b. THALLOGENS.

Plants with a mycelium. Growing in the shade. Never green. Fuxor.

Plants without a mycelium.

Growing in dry places, in the light. Lrchenes. Aquatic.

Germinating bodies in spiral, nut like cases. Characex. Germinating bodies in cells not spiral. ArG.r. 





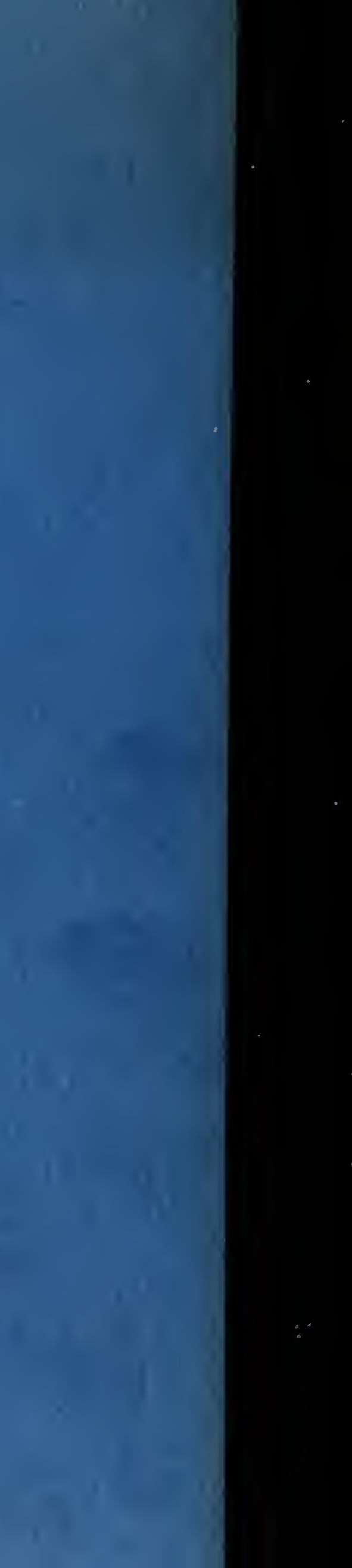

